\title{
Mathematical methodologies for calculating the mass diffusion coefficient of bananas during drying
}

\author{
Mariângela Amendola ${ }^{1}$ \& Marlene R. Queiroz ${ }^{1}$
}

\begin{abstract}
In this work two mathematical methodologies to solve the diffusion differential equation related to the banana drying process were used in order to obtain the mass diffusion coefficient value. A simplified mathematical model was considered that was based on Fick's Law, with initial and boundary conditions according to the experimental procedure carried out for banana drying. The first methodology was performed by using an approximation of the analytical solution and the second by using the numerical simulation according to the implicit scheme of the finite difference method. The calculation was carried out by looking for the minimal value of the norm calculated between the experimental data and the theoretical results obtained using different values of the diffusion coefficient. The algorithms associated with these methodologies were implemented with Matlab. The values of the diffusion coefficient according to the first and second methodologies were $1.65 \times 10^{-6}\left[\mathrm{~m}^{2} \mathrm{~h}^{-1}\right]$ and $1.58 \times 10^{-6}\left[\mathrm{~m}^{2} \mathrm{~h}^{-1}\right]$ respectively, with the associated minimal residual values of 0.0269 and 0.0257 .
\end{abstract}

Key words: finite differences method, implicit scheme, analytical solution, bananas, mass diffusion coefficient

\section{Metodologias matemáticas para cálculo do coeficiente de difusão de massa de bananas durante o processo de secagem}

\section{RESUMO}

Neste trabalho se utilizaram duas metodologias matemáticas visando resolver a equação diferencial de difusão aplicada ao processo de secagem de bananas e se obter o valor do coeficiente de difusão de massa. Considerou-se um modelo matemático simplificado, baseado na Lei de Fick, com condições inicial e de contorno de acordo com procedimento experimental conduzido em secagem de bananas; a primeira metodologia foi desenvolvida usando-se uma aproximação da solução analítica e a segunda, a simulação numérica, conforme o esquema implícito do método de diferenças finitas. O cálculo dos coeficientes foi conduzido procurando-se o valor mínimo da norma calculada entre os dados experimentais e os resultados teóricos obtidos com diferentes valores do coeficiente de difusão. Os algoritmos associados a essas metodologias foram implementados com o Matlab. Os valores do coeficiente de difusão, de acordo com as primeira e segunda metodologias, foram: $1,65 \times 10^{-6}\left[\mathrm{~m}^{2} \mathrm{~h}^{-1}\right]$ e 1,58 $\times 10^{-6}\left[\mathrm{~m}^{2} \mathrm{~h}^{-1}\right]$ respectivamente, com os valores dos resíduos mínimos associados de 0,0269 e 0,0257.

Palavras-chave: método das diferenças finitas, esquema implícito, solução analítica, bananas, coeficiente de difusão de massa 


\section{INTRODUCTION}

Knowing the drying kinetics, as well as the properties and parameters that characterize the drying process of agricultural products, has become important in supporting the development of technologies which can assure the conservation of the products. This experimental research area has shown improvements all over the world, as can be found in specific literature for post-harvest technology.

On the other hand, in Queiroz \& Nebra (1997), there are considerations about the advances of the theoretical approaches in this research area by using the theoretical methodology, as well as the mathematical model and the numerical methods used. In this sense, as related to mathematical models, those based on the liquid diffusion theory are cited as being preferred by the researchers that study the drying processes of agricultural products, mainly those with high moisture content (Lomauro \& Bakshi, 1985; Yusheng \& Poulsen, 1988; Lamberg, 1989; Mulet et al., 1989; Berna et al., 1990; Sereno \& Medeiros, 1990; Nogueira, 1991; Suarez \& Viollaz, 1991; Vagenas \& Marinos-Kouris, 1991a e 1991b). Furthermore, in relation to the numerical methodology used to solve diffusion models, the finite difference according to explicit or implicit schemes and control volume methods are the most often used methods (Silva \& Nebra, 1988; Kechaou \& Roques, 1989; Mulet et al., 1989; Sereno \& Medeiros, 1990; Fusco et al., 1991; Berthet et al., 1992).

Particularly at the College of Agricultural Engineering at the State University of Campinas (FEAGRI/UNICAMP), located in Brazil, most of the investigations related to drying process are performed using an approximation of the analytical solution of the Fick equation (Bossarino \& Amendola, 2004). Pioneer research work has been carried out using also applied mathematics as an important tool by Ito et al. (2002).

After that, several theoretical investigations have been performed at FEAGRI/UNICAMP to numerically simulate the heat transfer process associated with the experimental procedure of agricultural product drying. These investigations were carried out by using the finite difference methods according to the explicit scheme (Ito et al., 2003; Ito, 2003; Bossarino et al., 2005), and according to the implicit scheme (Amendola, 2005; Amendola \& Queiroz, 2005).

The goal of all the above cited investigations was to obtain the numerical value of parameters associated to the mathematical model of the heat transfer process.

Furthermore, investigations were carried out to compare the efficiency of the referred schemes of the finite difference methods, in terms of computational time and accuracy. In this sense, according to the results presented by Amendola \& Pirozzi (2004), the explicit scheme is as adequate as the implicit one for simulating the heat transfer process associated to the forced air pre-cooling process. However, according to Amendola (2005), to numerically simulate the soybean drying process, the computational time spent and the restrictions due to the stability criteria in the explicit scheme reveal the suitability of the implicit method.

It is noticed that a previous research using this theoreti- cal methodology of numerical simulation applied to banana drying was carried out by Queiroz \& Nebra (2001), but using the explicit scheme.

These observations lead to the investigation that follows in this paper, in spite of the fact that a more robust methodology (Campos Velho, 2001) associated with this inverse problem is still being developed.

\section{MATERIAL AND METHODS}

The mathematical model based on Fick's Second Law is that found in Brooker et al. (1992), which, as a first approach to reach the established objective of this paper, was simplified by considering that:

a) The drying process occurs inside a cylindrical region with length $L(m)$ and radius defined between $R_{1}=0(\mathrm{~m})$ and $R_{2}=0.01522(m)$, where $R_{2}$ is the initial radius of the bananas.

b) $\mathrm{R}_{2}<<\mathrm{L}$ (infinite cylinder).

c) The initial moisture content of the product, $\mathrm{M}_{0}$, is uniform in $\mathrm{r}$.

d) The surface moisture content of the product, $M_{e}$, is maintained fixed all over the drying process.

e) The product has an axial symmetry.

f) The diffusion coefficient is constant.

g) Shrinkage is neglected.

It is known that the diffusion coefficient is a function of temperature and moisture content. Also, drying of agricultural products with high initial moisture contents (such as fruits and vegetables) produces a considerable shrinkage effect. Finally, the boundary condition (d) implies that the fruit surface moisture content reaches the equilibrium moisture content instantaneously, which is not as realistic as the convective-type boundary condition. In this sense, Queiroz \& Nebra (2001) concluded that when the convective boundary condition and shrinkage phenomenon are included in the mathematical diffusion model, there is an improvement in the fitting process of the theoretical results to the experimental data. Here, these hypothesis were considered only to simplify the mathematical model in order to be able to compare two methodologies for solving the same mathematical model.

The equation that describes the process with these simplifications can be written as:

$$
\frac{\partial \mathrm{M}}{\partial \mathrm{t}}=\mathrm{D}\left[\frac{\partial \mathrm{M}}{\mathrm{r} \partial \mathrm{r}}+\frac{\partial}{\partial \mathrm{r}}\left(\frac{\partial \mathrm{M}}{\partial \mathrm{r}}\right)\right] ; \mathrm{R}_{1}<\mathrm{r}<\mathrm{R}_{2} \text { and } \mathrm{t}>0
$$

where:

$$
\begin{aligned}
& \mathrm{M} \text { - moisture content, db, decimal ( } \mathrm{kg} \text { water/kg dry } \\
& \quad \text { matter) } \\
& \mathrm{t} \text { - time coordinate }(\mathrm{t}) \\
& \mathrm{D} \text { - diffusion coefficient }\left(\mathrm{m}^{2} \mathrm{~h}^{-1}\right) \\
& \mathrm{r} \text { - radial coordinate }(\mathrm{m})
\end{aligned}
$$

According to the experimental procedures of banana drying and the simplifications considered, the following initial and boundary conditions must be associated: 


$$
\begin{aligned}
& M(r, 0)=M_{0} ; r \in\left(R_{1}, R_{2}\right) \\
& \left.\frac{\partial M}{\partial r}\right|_{r=R_{1}}=0 ; t>0 \\
& M\left(R_{2}, t\right)=M_{e} ; t>0
\end{aligned}
$$

where:

$$
\begin{aligned}
\mathrm{M}_{0} \text { - initial moisture content, } \mathrm{db} \text {, decimal (kg water/ } & \\
& \text { kg dry matter) } \\
\mathrm{M}_{\mathrm{e}}- & \text { equilibrium moisture content, db, decimal (kg } \\
& \text { water/kg dry matter) }
\end{aligned}
$$

As it is known from the literature (Crank, 1975), the analytical solution of the Eq. 1 with the initial and boundary conditions (2), (3) and (4) is:

$$
\frac{M(t)-M_{e}}{M_{0}-M_{e}}=\sum_{n=1}^{\infty} \frac{4}{R_{0} \alpha_{n}} \exp \left(-D \alpha_{n}^{2} t\right)
$$

where:

$$
\begin{aligned}
& \mathrm{M}(\mathrm{t}) \text { - } \text { average moisture content in time } \mathrm{t} \text {, db, decimal (kg } \\
& \text { water/kg dry matter) } \\
& \mathrm{R}_{0} \text { - initial radius of the banana transversal section (m) } \\
& \alpha_{\mathrm{n}} \text { - roots of } \mathrm{J}_{0}\left[\mathrm{R}_{0} \alpha_{\mathrm{n}}\right]=0 \\
& \mathrm{~J}_{0} \text { - order zero Bessel function }
\end{aligned}
$$

However, as can be noted in Eq. 5, this solution appears as an infinite series. So, in order to be useful to calculate the numerical values of $\mathrm{M}(\mathrm{t})$, only approximations of Eq. 5 can be considered, which are carried out by cutting off a number of its terms. Previous studies (Queiroz \& Nebra, 1997) suggested that no more than five terms are necessary to reach the same accuracy to this approximation.

It can also be noted that this analytical solution was possible only due to those above-mentioned hypothesis (from a to g). The inclusion of other variable or phenomena (such as the variability of the diffusion coefficient) could require a numerical solution.

In this sense, but as another way to get approximate results to the same mathematical model, as it is known, the Eq. 1 with initial and boundary conditions (2), (3), and (4) can also be solved by several classical numerical methods as those based on the finite differences, finite volume and finite elements. As the mathematical model considered in this work is one-dimensional, some numerical scheme based on the finite difference method could be chosen. So, the finite differences method according to the implicit scheme (Amendola, 2005) was chosen. To do that, first the following convention is defined:

$$
M_{j}^{i}=M(i \Delta t, j \Delta r), \text { for } j=1, \ldots N x \text { and } i=1, \ldots N t
$$

where:

$$
\begin{aligned}
& \Delta \mathrm{t} \text { - time interval of the process } \\
& \Delta \mathrm{r}-\text { spatial interval inside the product } \\
& \mathrm{Nx} \text { - number of points in the spatial mesh } \\
& \mathrm{Nt} \text { - number of integrations along the time }
\end{aligned}
$$

This convention and the chosen scheme transform equations (1), (2), (3) and (4) in their discretized form are used to determine $\mathrm{M}_{\mathrm{j}}{ }^{\mathrm{i}}=\mathrm{M}(\mathrm{jDr}, \mathrm{iDt})$ :

$$
\text { fo }\left(1-\frac{\Delta r}{r(j)}\right) M_{j-1}^{i}+\left(\text { fo }\left(-2+\frac{\Delta r}{r(j)}\right)-1\right) M_{j}^{i}+\text { fo }_{j+1}^{i}=-M_{j}^{i-1}
$$

for $\mathrm{i}=2, \ldots$ Nt and $\mathrm{j}=1, \ldots \mathrm{Nx}$

$$
\begin{aligned}
& M_{j}^{1}=M_{0} ; j=1, \ldots N x \\
& M_{1}^{i}=M_{2}^{i} ; i=1, \ldots N t \\
& M_{N x}^{i}=M_{e} ; i=1, \ldots N t
\end{aligned}
$$

where:

$$
\begin{aligned}
& \text { fo - discretized Fourier number }=D\left(\Delta t / \Delta r^{2}\right) \\
& r(j) \text { - distance j } \Delta r \text { from the center } R_{1}
\end{aligned}
$$

It must be pointed out that this system, as generated by an inverse problem, is ill-conditioned and that a specific theoretical methodology that could be used is beyond the scope of this work.

Expression (7) with the initial and boundary conditions (8), (9) and (10) allows us to calculate $\mathrm{M}(\mathrm{i} \Delta \mathrm{t}, \mathrm{j} \Delta \mathrm{r})$, for $\mathrm{j}=1, \ldots \mathrm{Nx}$ at each $\mathrm{i}$ time step.

The spatial numerical integration of these values at each time interval results in the theoretical average moisture content in the section represented by the following expression:

$$
\bar{M}(t)=\frac{1}{\pi R^{2}} \int_{0}^{R} M(r, t) 2 \pi r d r
$$

where:

$\overline{\mathrm{M}}(\mathrm{t})$ - theoretical average moisture content, $\mathrm{db}$, decimal (kg water/kg dry matter)

After analyzing the mesh size influence, the best $\mathrm{D}$ values can be determined by searching the minimal residual values calculated between the experimental moisture content value and the theoretical one for several $\mathrm{D}$ values, as:

$$
\left\|\overline{\mathrm{M}}_{\text {experimental }}-\overline{\mathrm{M}}_{\text {theoretical }}\right\|=\sqrt{\sum_{\mathrm{i}}^{\mathrm{N} \mathrm{t}}\left(\mathrm{M}_{\text {experimental }}^{\mathrm{i}}-\mathrm{M}_{\text {theoretical }}^{\mathrm{i}}\right)^{2}}
$$

This is carried out by taking some initial estimative of the $\mathrm{D}$ value selected from the literature.

All of the referred algorithms are implemented with Matlab scientific computational environment.

The experimental data were obtained from Queiroz (1994) for banana drying under the following drying conditions: temperature of $50{ }^{\circ} \mathrm{C}$ and relative humidity of $20 \%$. The experimental moisture content values were recorded approximately hourly during $40 \mathrm{~h}$. According to the experimental procedure described in Queiroz (1994), fixed parameters were: $\mathrm{M}_{0}=3.21$ (db, decimal) and $\mathrm{M}_{\mathrm{e}}=0.0559$ (db, decimal).

\section{RESULTS AND DISCUSSION}

As the literature suggests, the best value of $\mathrm{D}$ among initial estimative belonging to $[1.5,2.5] \times 10^{-6}\left(\mathrm{~m}^{2} \mathrm{~h}^{-1}\right)$ interval was investigated. 
Considering an arbitrary fixed D value in this interval and the temporal mesh as having $1 \mathrm{~h}$, the size of the spatial mesh could be defined as having 180 points. This was established by carrying out numerical experiments from a coarse mesh until reaching one where the difference in the numerical results of $\mathrm{M}$ could be disregarded.

Using the adequate mesh size, numerical simulations were carried out by using all these D values, and the referred residual values were calculated for analysis. The experimental data and theoretical values obtained for all these D values are shown in Figure 1.

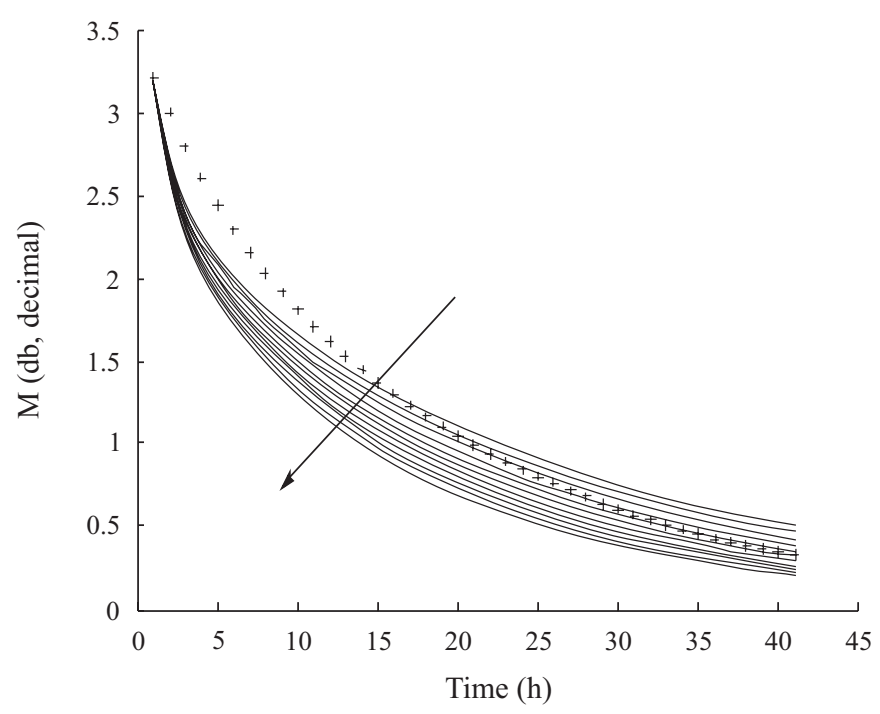

Figure 1. Curves obtained from experimental data (+) and from numerical results (continuous lines) for $D$ value in $[1.5,2.5] \times 10^{-6} \mathrm{~m}^{2} \mathrm{~h}^{-1}$

In Figure 1 the lines are drawn continuously simply to help their visualization, and the arrow indicates the direction $\mathrm{D}$ values increase.

Figure 2 shows the residual values obtained as a function

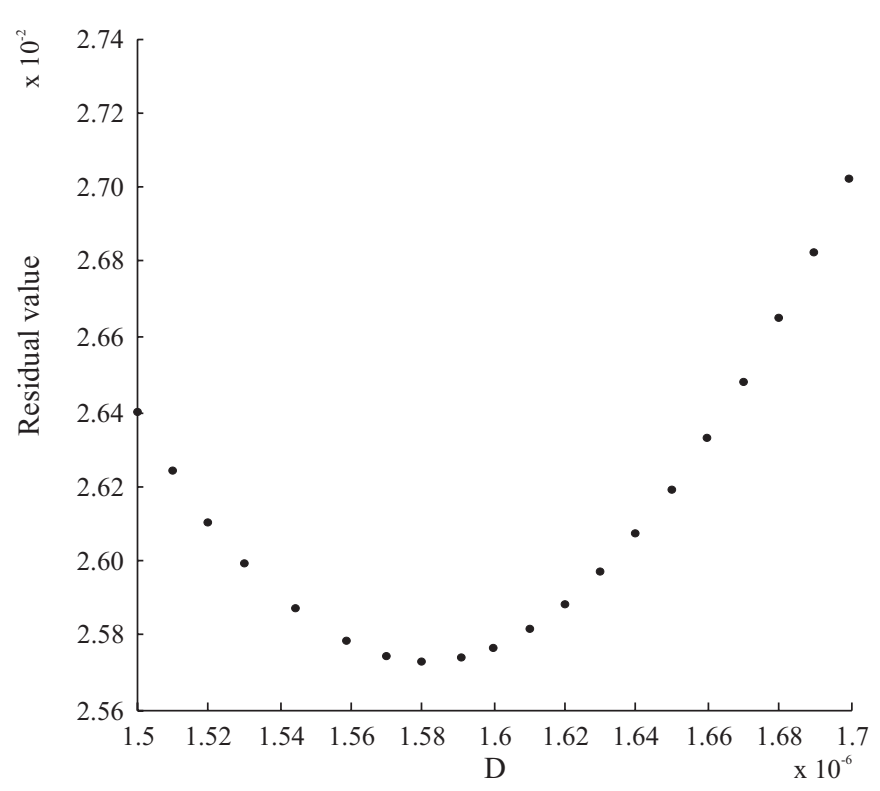

Figure 2. Residual values as a function of $D$ values $\left(m^{2} h^{-1}\right)$ of the all referred $\mathrm{D}$ values but in a more refined interval: $[1.5,1.7] \times 10^{-6} \mathrm{~m}^{2} \mathrm{~h}^{-1}$.

Analysis of the results leads to the conclusion that the best $\mathrm{D}$ value is approximately $1.58 \times 10^{-6}\left(\mathrm{~m}^{2} \mathrm{~h}^{-1}\right)$, with residual value of 0.0257 .

In order to compare this numerical result to the theoretical result obtained by using 5 terms of the analytical solution, we also carried out the same kind of comparison of residual values for the determination of the best $\mathrm{D}$ value. In this case, the best $D$ value is $1.65 \times 10^{-6}\left(\mathrm{~m}^{2} \mathrm{~h}^{-1}\right)$, with a residual value of 0.0269 . These results, as well as the numerical one previously obtained, are shown in Figure 3. In this figure the continuous line is just to help the comparison.

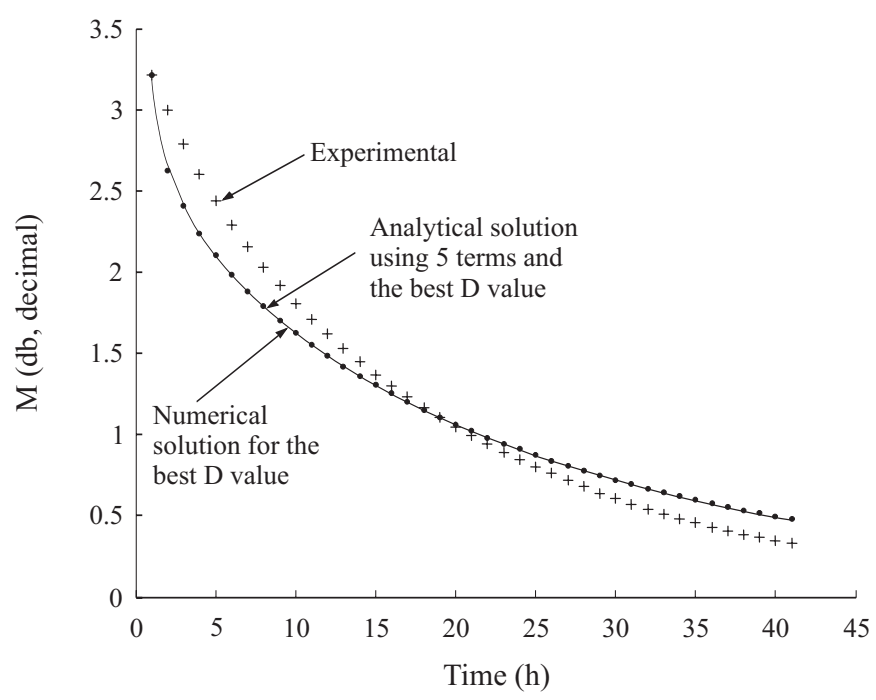

Figure 3. Curves obtained from experimental data $(+)$, numerical solution (continuous) and analytical solution with 5 terms $(\bullet)$, both for the associated best $D$ value

\section{CONCLUSIONS}

1. The drying curve generated with data obtained from numerical simulation by using the implicit scheme is as representative of the drying process as the curve generated through analytical solution using 5 terms.

2. The mass diffusion coefficient which must be associated to banana drying can be determined using the implicit numerical method or the analytical solutions.

3 . The mass diffusion coefficient values obtained were $1.65 \times 10^{-6}\left(\mathrm{~m}^{2} \mathrm{~h}^{-1}\right)$ from the analytical solution with 5 terms and $1.58 \times 10^{-6}\left(\mathrm{~m}^{2} \mathrm{~h}^{-1}\right)$ from the numerical solution with the implicit scheme.

4. The numerical simulation methodology is recommended as the most adequate one for the completion of this kind of investigation if looking for the use of more complex mathematical models.

\section{ACKNOWLEDGEMENTS}

The authors would like to thank the Scientific Committee 
of the XXVI Iberian Latin-American Congress on Computational Methods in Engineering - CILAMCE 2005 for the opportunity to present and to discuss these results.

To the students' interest and motivation in the "Teorias Avançadas do Processo de Secagem” class (Feagri/Unicamp) to the continuity of this research using the implicit scheme.

\section{LITERATURE CITED}

Amendola, M. Considerations to continue researches in drying process numerical simulation of agriculture products at FEAGRI/ UNICAMP. In: National Congress on Computational Mechanics, 8, 2005, Austin, TX. Abstracts... Austin, 2005. CD Rom.

Amendola, M.; Pirozzi, D. C. Z. Considerations to continue the research in the precooling area of numerical simulation of agriculture products at FEAGRI/UNICAMP. In: International Postharvest Symposium, 5, 2004, Verona. Abstracts... Verona, 2004. v.1, p.71.

Amendola, M.; Queiroz, M. R. Mathematical modelling and numerical simulation of drying processes to identify the mass diffusion coefficient of bananas. In: Iberian Latin-American Congress on Computational methods in Engineering-CILAMCE, 26, 2005, Guarapari. Proceedings... Guarapari: CILAMCE, 2005. CD Rom.

Berna, A.; Rosselo, C.; Canellas, J.; Mulet, A. Drying kinetics of apricots. In: Spiess, W. E. L.; Shubert, H. (eds.) Engineering and food. Barking: Elsevier Science Publishing, 1990. v.1, p. 628-636.

Berthet, D.; Bakhouya, A.; Bouzon, J.; Vergnaud, J. M. Drying of polymers. Modeling with diffusion-evaporation and shrinkage. In: Mujumdar, A. S. (ed.) Drying'92: Proceedings of the 8th International Drying Symposium. Amsterdan: Elsevier Science Publishing, 1992. part A, p. 364-373.

Bossarino, D.; Amendola, M. Elaboração de um programa computacional no MATLAB como fruto da revisão bibliográfica de estudos de processos de secagem de produtos agrícolas. In: Congresso Interno de Iniciação Científica da UNICAMP, 12, 2004, Campinas. Resumos... Campinas: UNICAMP, 2004. CD Rom.

Bossarino, D.; Amendola, M.; Gaspar, C. R. Simulação computacional para a determinação de propriedades de grãos submetidos a um tipo de secagem. In: Congresso Nacional de Matemática Aplicada e Computacional - CNMAC, 28, 2005, São Paulo. Anais... São Carlos: SBMAC, 2005. CD Rom.

Brooker, D. B.; Bakker-Arkema, F. W.; Hall, C. W. Drying and storage of grains and oilseeds. New York: AVI Book, 1992. 450p.

Campos Velho, H. F. Mini-Curso - Problemas inversos: conceitos básicos e aplicações. In: Encontro de Modelagem Computacional, 4, 2001, Nova Friburgo. Anais... São Carlos: SBMAC, 2001 p.63-79.

Crank, J. The mathematics of diffusion. 2.ed. Oxford: Oxford University Press, 1975. 414p.

Fusco, A. J.; Avanza, J. R.; Aguerre, R. J.; Gabitto, J. F. Diffusional model for drying with volume change. Drying Technology, New York, v.9, n.2, p. 397-417, 1991.
Ito, A. P. Determinação de condutividade e difusividade térmica de soja. Campinas: UNICAMP, 2003. 91p. Dissertação Mestrado

Ito, A. P.; Amendola, M.; Park, K. J. Construção e avaliação de um sistema de determinação de condutividade e difusividade térmica em regime transiente. Simiente, Santiago de Chile, v.72, n.3/4, p.141-2, 2002.

Ito, A. P.; Amendola, M.; Park, K. J. Determinação da condutividade térmica de grãos de soja. Revista Iberoamericana de Tecnologia Poscosecha, México, v.5, n.2, p.82-85, 2003.

Kechaou, N.; Roques, M. A. A variable diffusivity model for drying of highly deformable materials. In: Mujumdar, A.S.; Roques, M. (eds.) Drying'89. New York: Hemisphere Publishing Corporation, 1989. p.332-338

Lamberg, I. Studies of water transport phenomena during potato drying Journal of Food Process Engineering, Connecticut, v.10, n.4, p. 285-299, 1989.

Lomauro, C. J.; Bakshi, A. S. Finite element analysis of moisture diffusion in stored foods. Journal of Food Science, Chicago, v.50, p. 392-396, 1985.

Mulet, A.; Berna, A.; Rossello, C. Drying of carrots. I. Drying models. Drying Technology, New York, v.7, n.3, p.537557, 1989.

Nogueira, R. I. Processo de secagem de banana (Musa acuminata subgrupo Cavendish cultivar Nanica): parâmetros ótimos na obtenção de banana-passa. Campinas: UNICAMP, 1991. 154p. Dissertação Mestrado

Queiroz, M. R. Estudo teórico experimental da cinética de secagem de bananas. Campinas: UNICAMP, 1994. 176p. Tese Doutorado

Queiroz, M. R.; Nebra, S. A. Soluções analítica e numérica do modelo de difusão aplicadas à secagem de bananas. Engenharia Agrícola, Jaboticabal, v.17, n.1, p.74-83, 1997.

Queiroz, M. R.; Nebra, S. A. Theoretical and experimental analysis of the drying kinetics of bananas. Journal of Food Engineering, Essex, v.47, n.2, p.127-132, 2001.

Sereno, A. M.; Medeiros, G. L. Simplified model for the prediction of drying rates for foods. Journal of Food Engineering, Barking, v.12, n.1, p.1-11, 1990.

Silva, M. A.; Nebra, S. A. The calculation of moisture distribution in a drying process. In: International Drying Symposium, 6, 1988, Versailles. Proceedings ... Versailles, 1988. p.145-150.

Suarez, C.; Viollaz, P. E. Shrinkage effect on drying behaviour of potato slabs. Journal of Food Engineering, Barking, v.13, n.2, p.103-114, 1991.

Vagenas, G. K.; Marinos-Kouris, D. Drying kinetics of apricots. Drying Technology, New York, v.9, n.3, p.735-752, 1991a.

Vagenas, G. K.; Marinos-Kouris, D. Finite element simulation of drying of agricultural products with volumetric changes. Applied Mathematical Modelling, New York, v.15, n.9, p.475-482, $1991 b$.

Yusheng, Z.; Poulsen, K. P. Diffusion in potato drying. Journal of Food Engineering, Barking, v.7, n.4, p.249-262, 1988. 